\title{
ДИСКУССИИ, БИБЛИОГРАФИЯ, ОБЗОРЫ
}

Д. чл. А. В. КОЗЛОВ,* д. чл. С. Ю. СТЕПАНОВ,**

P. С. ПАЛАМАРЧУК, ${ }^{*}$ д. чл. А. М. МИНИБАЕВ*

\section{ОНТОГЕНИЧЕСКИЕ ОРИЕНТИРЫ ДЛЯ ВЫБОРА МОДЕЛИ ФОРМИРОВАНИЯ ПЛАТИНОВОГО ОРУДЕНЕНИЯ В ЗОНАЛЬНЫХ КЛИНОПИРОКСЕНИТ-ДУНИТОВЫХ МАССИВАХ УРАЛА ${ }^{1}$}

\author{
* Санкт-Петербургский горный университет, \\ 199106, Санкт-Петербург, 21 линия, 2; \\ e-mail:akozlov@spmi.ru \\ ** Институт геологии и геохимии им. академика А. Н. Заварицкого УрО РАН, \\ 620016, Екатеринбург, ул. Академика Вонсовского, 15
}

В статье обсуждаются результаты онтогенических исследований раннего парагенезиса рудных минералов в зональных клинопироксенит-дунитовых массивах Среднего Урала. Показано, что образование этих минералов происходило в следующей последовательности: иридистый осмий $\rightarrow$ хромшпинель $\rightarrow$ лаурит-эрликманит $\rightarrow$ осмистый иридий $\rightarrow$ изоферроплатина. Выявленные онтогенические признаки рудных фаз хорошо согласуются с моделями, предполагающими концентрирование металлов платиновой группы на магматическом этапе эволюции клинопироксенит-дунитовых массивов из расплава, до проявления наложенных процессов высокотемпературной пластической деформации.

Ключевые слова: онтогения, хромшпинель, платина, осмий, иридий, рудный парагенезис, клинопироксенит-дунитовые массивы, Средний Урал.

A. V. KOZLOV, S. Yu. STEPANOV,** R. S. PALAMARCHUK,*A. M. MINIBAYEV.* ONTOGENETIC ORIENTATIONS TO CHOOSE THE MODEL OF THE FORMATION OF PLATINUM-BEARING MINERALIZATION IN ZONAL CLINOPYROXENITE-DUNITE MASSIFS OF THE URALS

* Saint Petersburg Mining University, Saint Petersburg, Russia ** Zavaritsky Institute of Geology and Geochemistry, Ural Branch RAS, Yekaterinburg, Russia

Results of ontogenetic studies of the early paragenesis of ore minerals in zonal clinopyroxenitedunite massifes of the Middle Urals are discussed. It is shown that the formation of these minerals occurs in the following order: iridosmium $\rightarrow$ chrome-spinel $\rightarrow$ laurite-erlichmanite $\rightarrow$ osmiridi$\mathrm{um} \rightarrow$ isoferroplatinum. Revealed ontogenic features of ore phases are in good agreement with

${ }^{1}$ Редакционная коллегия журнала считает необходимым выделить содержащиеся в данной статье наиболее дискуссионные положения: 1. Авторская трактовка приведенных в статье онтогенических особенностей минералов в ряде случаев неоднозначна. 2. Вследствие субъективности выводов, вытекающих из рассмотрения онтогенических особенностей минералов, возникает вопрос о надежности указанных причинно-следственных связей между рассмотренными явлениями на уровне минеральных индивидов и выводами значительно более крупного масштаба - в целом о генезисе и поисковых критериях платинометалльного оруденения в зональных клинопироксенит-дунитовых массивах Урала. 
models suggesting the concentration of platinum group metals at the magmatic stage of evolution of the clinopyroxenite-dunite massif before display of the superimposed high-temperature plastic deformation.

Key words: ontogenetic studies, chrome-spinel, native platinum, osmium, iridium, paragenesis, clinopyroxenite-dunite massifs, the Middle Urals.

Первые находки коренной платины были сделаны на Нижнетагильском массиве в 1824 г. (Карпинский, 1893). С тех пор практически непрерывно продолжается изучение коренной платиноносности в зональных клинопироксенит-дунитовых массивах Урала (Мосин, 2002). Уже в ранних публикациях (Высоцкий, 1913; Карпинский, 1926; Заварицкий, 1928; Бетехтин, 1935; и др.) были описаны почти все геолого-минералогические особенности ее проявления, на основе чего возник широкий спектр генетических представлений, от ортомагматической модели А. Н. Заварицкого до флюидо-динамической модели А. П. Карпинского. Следует подчеркнуть, что, несмотря на диаметрально противоположные взгляды этих исследователей на условия образования платиновой минерализации, А. П. Карпинский не отрицал принципиальной возможности выделения какой-то части платиновой минерализации на магматическом этапе в более глубинных частях магматических резервуаров (Карпинский, 1926), а А. Н. Заварицкий, опираясь на наличие флюидных включений в хромшпинели, не исключал участия флюидных процессов в формировании хромитовой и платиновой минерализации (Заварицкий, 1928).

Хотя современные исследования месторождений платиновых металлов в зональных клинопироксенит-дунитовых массивах, основанные на использовании высокочувствительных методов локального анализа минералов, позволили уточнить структурно-вещественные особенности платиновой минерализации (Волченко, 1986; Иванов, 1997; Малич и др., 1997; Johan, 2002; Malitch, Thalhammer, 2002; Толстых, 2004; Auge et al., 2005; Пушкарев и др., 2007; Толстых и др., 2011; Иванов, 2011; Малич и др., 2015), так и не было достигнуто единство в генетической интерпретации полученных данных.

Из анализа результатов ранее проведенных исследований становится ясным, что существуют достаточно убедительные свидетельства проявления минералообразующих процессов с участием металлов платиновой группы на всех этапах формирования клинопироксенит-дунитовых массивов. Важно понять, на каком этапе произошло концентрирование платиноидов, определяющее промышленную ценность их рудопроявлений. Для решения поставленной задачи нами было проведено исследование онтогенических особенностей минеральных агрегатов, содержащих минералы металлов платиной группы. Поскольку не удалось наблюдать взаимоотношения этих минералов с породообразующим оливином, главное внимание было уделено детальному изучению взаимоотношений минералов рудного парагенезиса.

В рамках онтогенического цикла минеральные индивиды зарождаются, растут и разрушаются, оставляя следы проявления этих процессов в своих морфологических и конституционных особенностях (Григорьев, 1961). При этом конвергентность ряда онтогенических признаков, а также частичная или полная их утрата в результате проявления наложенных процессов, не всегда позволяют дать этим признакам однозначную генетическую интерпретацию. Учитывая сказанное, авторы считают генетические выводы, полученные в ходе проведенного исследования, открытыми для дискуссии. 


\section{МЕТОДЫ ИССЛЕДОВАНИЯ}

В основу исследования была положена коллекция минералов платиновой группы из хромититов Светлоборского, Вересовоборского и Каменушенского клинопироксенит-дунитовых массивов, собранная авторами. Оптическая диагностика минералов сопровождалась изучением их химического состава методом электронно-зондового микроанализа (JEOL-JSM6390LV, ИГГ УрО РАН, Екатеринбург; CamScan MX2500, ВСЕГЕИ, Санкт-Петербург и Tescan VEGA, Горный университет, Санкт-Петербург). Химический состав минералов платиновой группы изучался методом рентгеноспектрального микроанализа (микроанализатор СAMECA SX 100 с пятью волновыми спектрометрами, ИГГ УрО РАН, Екатеринбург).

\section{СТРУКТУРНО-ВЕЩЕСТВЕННЫЕ ОСОБЕННОСТИ ВЗАИМООТНОШЕНИЯ ХРОМШПИНЕЛИДОВ С МИНЕРАЛАМИ МЕТАЛЛОВ ПЛАТИНОВОЙ ГРУППЫ}

Большинством исследователей платиновой минерализации уральских месторождений отмечается ее теснейшая пространственная и генетическая связь с хромшпинелидами, образующими сегрегации в дунитах. Рассматриваются как магматическая (Высоцкий, 1913; Бетехтин, 1935; Заварицкий, 1928; Толстых и др., 2004; и др.), так и эпигенетическая (Карпинский, 1926; Иванов, 1997; Генкин, 1997; Пушкарев и др., 2007, 2015) модели генезиса дунит-хромититовой ассоциации.

С учетом длительной истории становления клинопироксенит-дунитовых массивов, для понимания генезиса платиноидного оруденения важно выделить сингенетичные структуры, которые отражают процессы первичного образования минералов. Поэтому именно на изучение раннего рудного парагенезиса, в который входят хромшпинель, изоферроплатина, твердые растворы осмияиридия и лаурит-эрликманит, были направлены более ранние исследования (Толстых и др., 2011; Степанов, 2015; Степанов и др., 2017). Изучение платиноносных хромититов привело исследователей к заключению о более высокой степени идиоморфизма хромшпинели по отношению к самородной платине. Действительно, в подавляющем большинстве случаев можно наблюдать цементацию более идиоморфных зерен хромшпинели агрегатами зерен платины (рис. 1, a). Можно наблюдать и отдельные идиоморфные индивиды хромшпинели в платине (рис. 1, б).

Существенно реже наблюдаются обратные взаимоотношения, когда в хромшпинели встречаются более идиоморфные зерна платины. На совместное нахождение идиоморфных и ксеноморфных зерен платины в хромшпинели обратил внимание А. Г. Бетехтин (Бетехтин, 1935). В одном из задокументированных случаев (рис. 2) предполагалось, что идиоморфный кристалл платины является метакристаллом, а не более ранним по отношению к хромшпинели выделением. Так же А. Г. Бетехтиным отмечалась идентичность состава как ксеноморфных, так и идиоморфных выделений платины по данным доступных на тот момент методов исследования (травлению, определению твердости и другим физическим признакам). Нам также удалось наблюдать «идиоморфное» выделение изоферроплатины в идиоморфном по отношению к окружающей его изоферроплатине кристалле хромшпинели (рис. 3). 

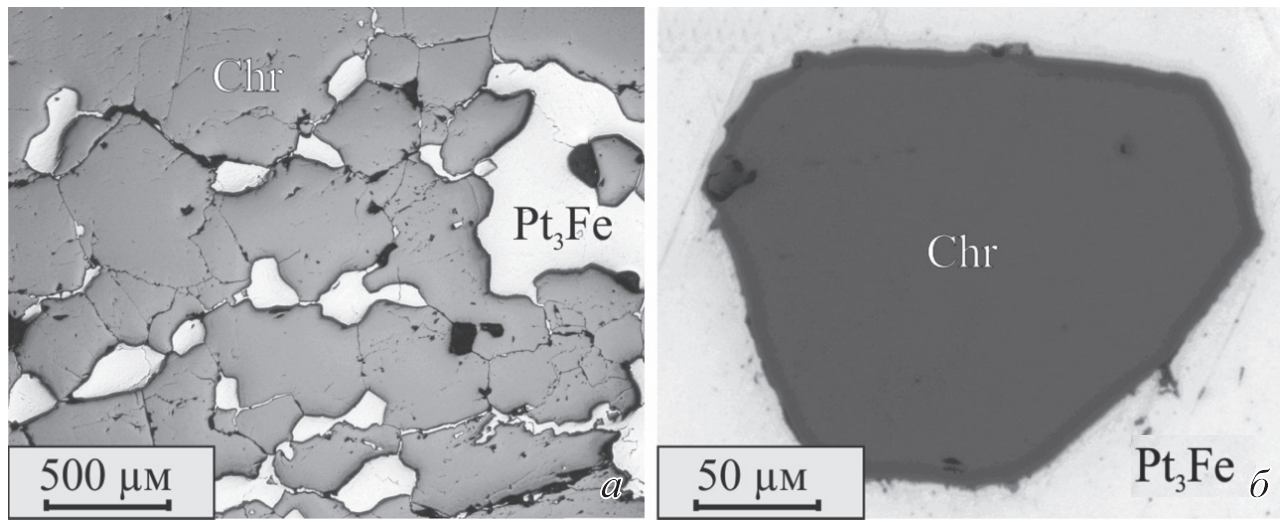

Рис. 1. Идиоморфизм хромшпинели (Chr) по отношению к изоферроплатине $\left(\mathrm{Pt}_{3} \mathrm{Fe}\right)$. Вересовоборский массив.

$a$ - размещение изоферроплатины в интерстициях между кристаллами хромшпинели, $\sigma$ - идиоморфный кристалл хромшпинели в изоферроплатине.

Fig. 1. Idiomorphism of chrome-spinel (Chr) regarding isoferroplatinum $\left(\mathrm{Pt}_{3} \mathrm{Fe}\right)$. Veresovoborsky massif.

Анализ морфологических особенностей выделений этих двух минералов показывает, что ориентировка «граней» идиоморфного выделения изоферроплатины совпадает с ориентировкой граней кристалла хромшпинели (рис. 3). Следовательно, форма выделения платины определяется огранкой полости в зерне хромшпинели и соответствует форме образовавшегося в ней отрицательного кристалла. Такие взаимоотношения можно интерпретировать как:

- результат захвата растущим кристаллом хромшпинели фрагмента железоплатинового расплава с выполнением им полости в виде отрицательного кристалла;

- метакристалл изоферроплатины, образовавшийся в результате метасоматического замещения хромшпинели платиной;

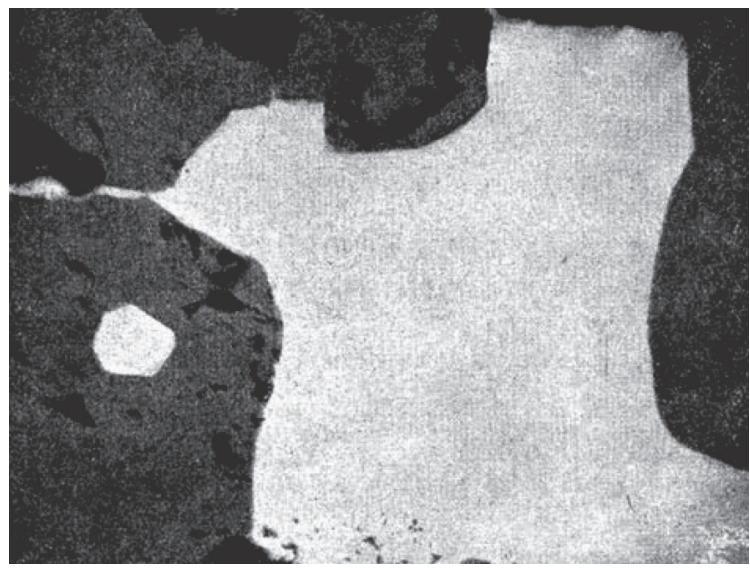

Рис. 2. Сонахождение идиоморфных и ксеноморфных выделений платины в хромшпинели (фотография из монографии А. Г. Бетехтина, 1935).

Fig. 2. Coexistence of idiomorphous and xenomorphous segregations of platinum inside chrome-spinel (after Betekhtin, 1935). 


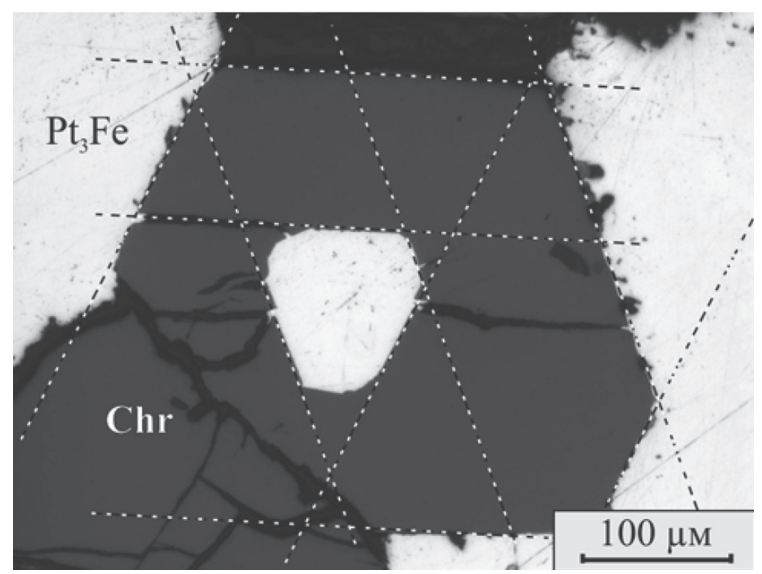

Рис. 3. Выделение изоферроплатины, выполняющее полость в виде отрицательного кристалла в идиоморфном кристалле хромшпинели. Вересовоборский массив. Пояснения в тексте.

Fig. 3. Segregation of isoferroplatinum filling the cavity shaped as a negative crystal inside the idiomorphous chrome-spinel crystal. Veresovoborsky massif.

— выполнение платиной ограненного углубления в ранее образованном кристалле хромшпинели;

— футляровидный метакристалл хромшпинели, образовавшийся в результате метасоматического замещения платины хромшпинелью;

- эпитаксическое зарождение хромшпинели на образованном ранее кристалле изоферроплатины.

Первые три варианта реализуются при более раннем образовании хромшпинели по сравнению с изоферроплатиной, а последние два - при обратных возрастных взаимоотношениях этих минералов.

Встречаются и действительно идиоморфные по отношению к хромшпинели кристаллы платины, что хорошо видно на рис. 4. Для этого кристалла характерно наличие закономерно ориентированных по отношению к его

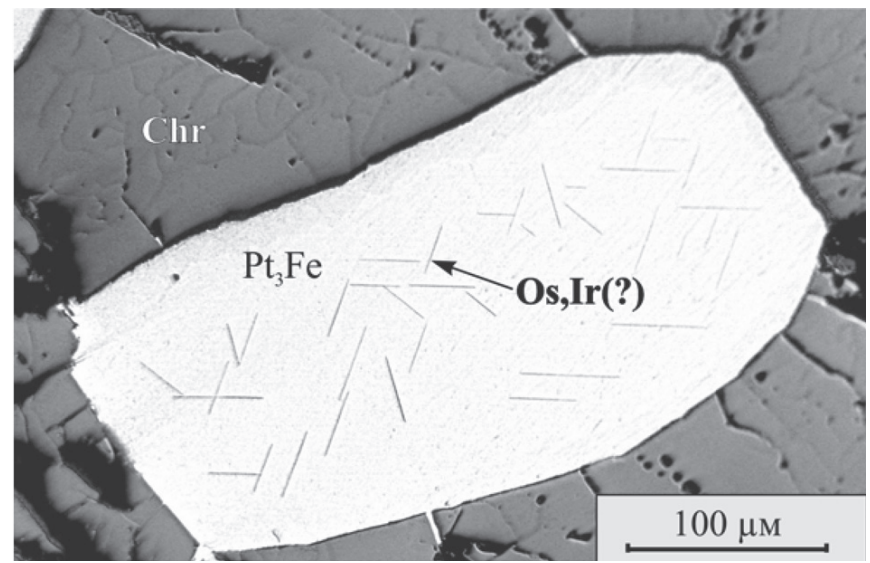

Рис. 4. Кристалл осмий-железо-платинового твердого раствора $\left(\mathrm{Pt}_{3} \mathrm{Fe}\right)$ с решетчатой структурой распада (?) идиоморфный по отношению к хромшпинели. Вересовоборский массив.

Fig. 4. Crystal of osmium-iron-platinum solid solution $\left(\mathrm{Pt}_{3} \mathrm{Fe}\right)$ with the lattice-like exsolution structure (?) that is idiomorphous regarding to chrome-spinel. Veresovoborsky massif. 


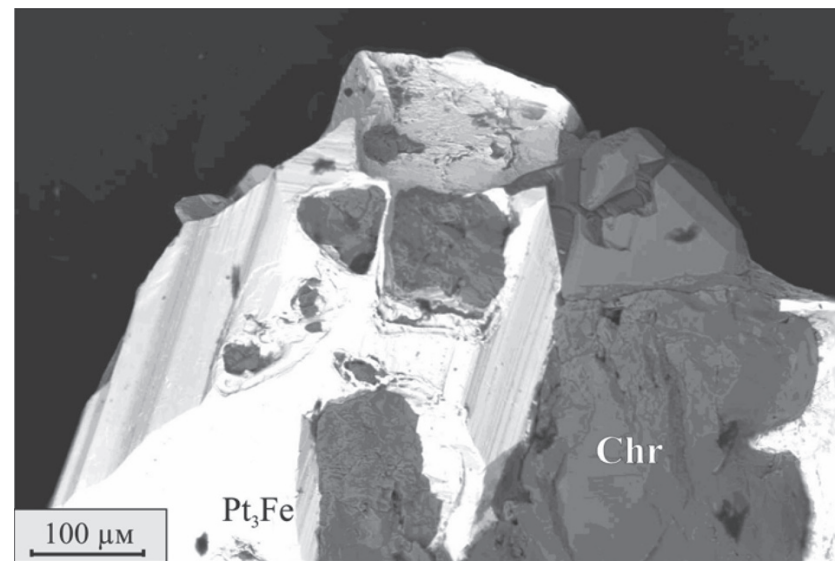

Рис. 5. Индукционные поверхности (?) между индивидами изоферроплатины и хромшпинели. На фотографии виден также идиоморфный кристалл хромшпинели (в верхнем правом углу). Иовское дунитовое тело, Конжаковский массив.

Fig. 5. Induction faces (?) between individuals of isoferroplatinum and chrome-spinel. Iov dunite body, Konzakovsky massif.

огранке тончайших пластинок самородного осмия, что напоминает структуру распада твердого раствора. Пластинчатые кристаллы осмия ориентированы по четырем направлениям, сохраняющимся в пределах всего зерна, что свидетельствует о его монокристальности. Некоторые из этих направлений параллельны фрагментам огранки кристалла (отдельным граням или ступеням на гранях). Наличие структуры распада твердого раствора осмия в самородной платине свидетельствует о более высокой температуре кристаллизации осмистой платины по сравнению с хромшпинелью.

С позиций магматического образования этого парагенезиса возможно более раннее образование платины при наличии в ней примесей тугоплавких платиноидов и более позднее, если она представлена изоферроплатиной. Учитывая переменный состав как хромшпинели, так и твердых растворов на основе платины, можно допустить и возможность совместной кристаллизации этих двух минералов из расплава в эвтектической области (Округин, 2011). Признаками совместного роста могут являться индукционные поверхности между индивидами этих минералов (рис. 5).

Таким образом, анализ пространственно-временных взаимоотношений изоферроплатины и хромшпинели позволяет сделать следующие выводы.

1. Выявлены признаки, позволяющие допустить все возможные варианты последовательности образования изоферроплатины и хромшпинели: более раннее образование хромшпинели, ее совместный рост с изоферроплатиной и более позднее образование хромшпинели.

2. Установленные взаимоотношения изоферроплатины и хромшпинели можно объяснить их совместной (эвтектической) кристаллизацией.

3. Возможность кристаллизации изоферроплатины из расплава хорошо согласуется с экспериментальными данными (Борисов, 2005).

Характерной особенностью изученных проявлений платиноидной минерализации является присутствие в изоферроплатине включений интерметаллических соединений, в первую очередь иридий-осмиевого состава. По результатам 68 рентгеноспектральных микроанализов пластинчатые кристаллы са- 

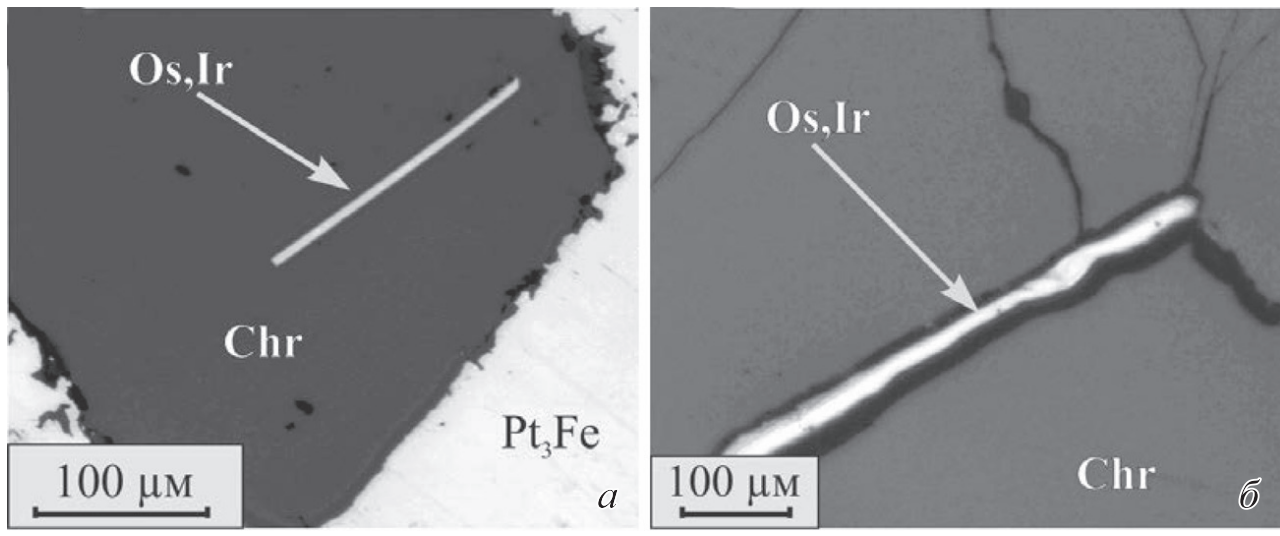

Рис. 6. Пластинчатые кристаллы самородного осмия (Os, Ir), образующие включения в идиоморфном кристалле хромшпинели $(a)$ и расположенные между кристаллами хромшпинели (б). Вересовоборский массив.

Fig. 6. Lamellar native osmium crystals (Os,Ir) formed inclusion into idiomorphous chrome-spinel crystal (a) and placed between chrome-spinel crystals (б). Veresovoborsky massif.

мородного осмия имеют переменный состав (мас. \%): Os 66.2-93.6 (среднее 78), Ir 4.4-29.8 (18), тогда как обогащенные иридием интерметаллиды, представленные включениями в изоферроплатине, содержат в среднем (мас. \%): Ir 44.3-84.8 (среднее 44.3), Os 3.8-35.8 (24.6), Pt 2.2-16.3 (9.4), Ru 1.811.6 (4.7), Rh $1.1-5.0$ (2.5).

Кристаллы иридистого осмия в виде идиоморфных пластинчатых индивидов часто наблюдаются в виде включений в кристаллах хромшпинели (рис. 6, $a$ ) или располагаются вблизи границ ее индивидов (рис. 6, б). В то же время они не образуют включений в оливине.

Встречаются пластинчатые кристаллы иридистого осмия, одно окончание которых находится в хромшпинели, а другое — в изоферроплатине (рис. 7). При этом со стороны изоферроплатины кристаллы иридистого осмия имеют скелетное строение (рис. 7, б).

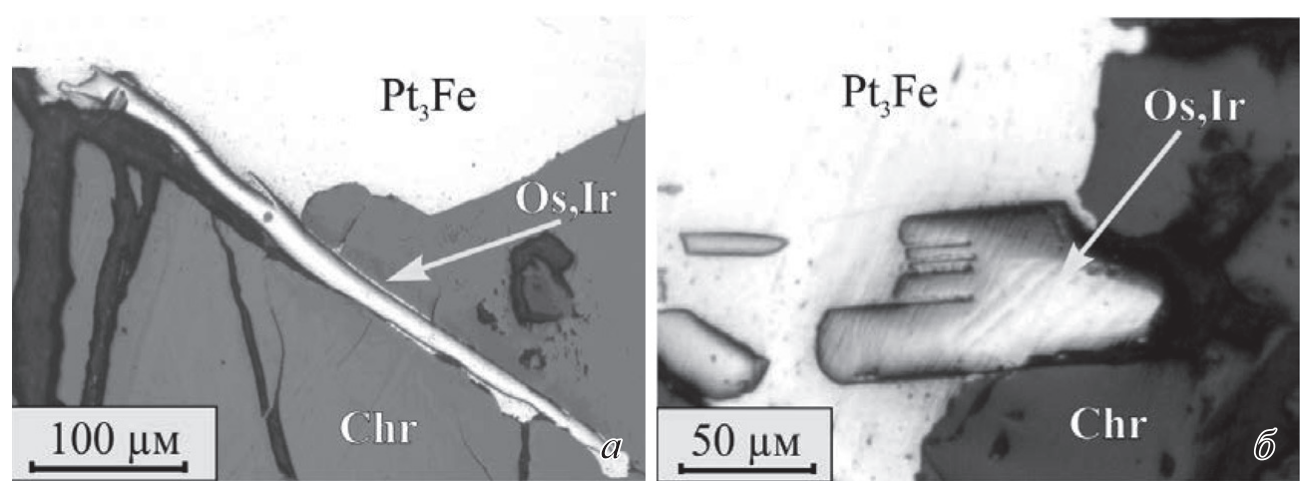

Рис. 7. Кристаллы самородного осмия, расположенные частично в изоферроплатине $(a)$ и хромшпинели с преобладающим ростом в сторону изоферроплатины (б). Хромититы Вересовоборского $(a)$ и Каменушенского массивов (б).

Fig. 7. Native osmium crystals occurring partly in isoferroplatinum $(a)$ and chrome-spinel with predominant growth toward isoferroplatinum (б). Chromitites of the Veresovoborsky $(a)$ and Kamenushensky massifs (б). 

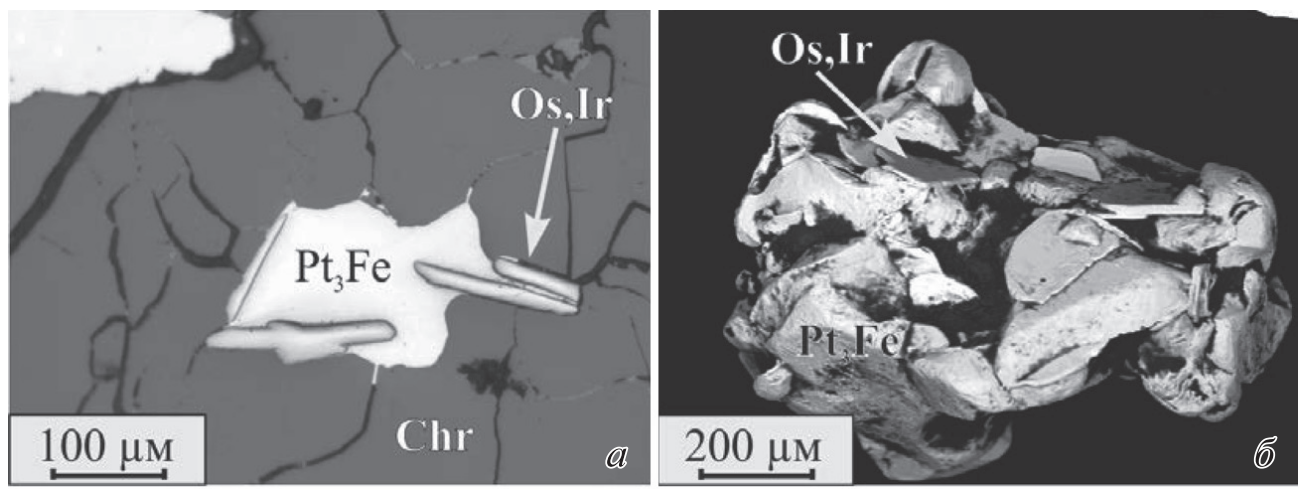

Рис. 8. Расположение пластинчатых кристаллов осмия на границе выделений изоферроплатины и хромшпинели. Нижнетагильский массив, фотография в отраженном свете $(a)$, Каменушенский массив, изображение в обратно-отраженных электронах (б).

Fig. 8. Confinedness of lamellar osmium crystals to boundaries between isoferroplatinum and chrome-spinel segregations. Nizhnetagilsky massif, photo in reflected light (a), Kamenushensky massif, BSE image.

Часто пластинчатые выделения иридистого осмия расположены на границах выделений платины с хромшпинелью (рис. 8). При наблюдении самородков платины из россыпей с использованием растрового электронного микроскопа выявлено облекание выделений платины пластинчатыми кристаллами осмия (рис. 8, б).

Кристаллы иридистого осмия, образующие включения в изоферроплатине, демонстрируют признаки скелетного роста (рис. 9). В процессе роста скелетных кристаллов иногда происходит смыкание отдельных ветвей скелета, что приводит к захвату изолированных фрагментов изоферроплатины в объеме кристаллов иридистого осмия. Захваченные фрагменты часто имеют форму, соответствующую отрицательным кристаллам иридистого осмия (рис. 10). Такие взаимоотношения двух минералов могут возникнуть или в результате захвата расплава изоферроплатины растущими кристаллами осмия, или в ре-
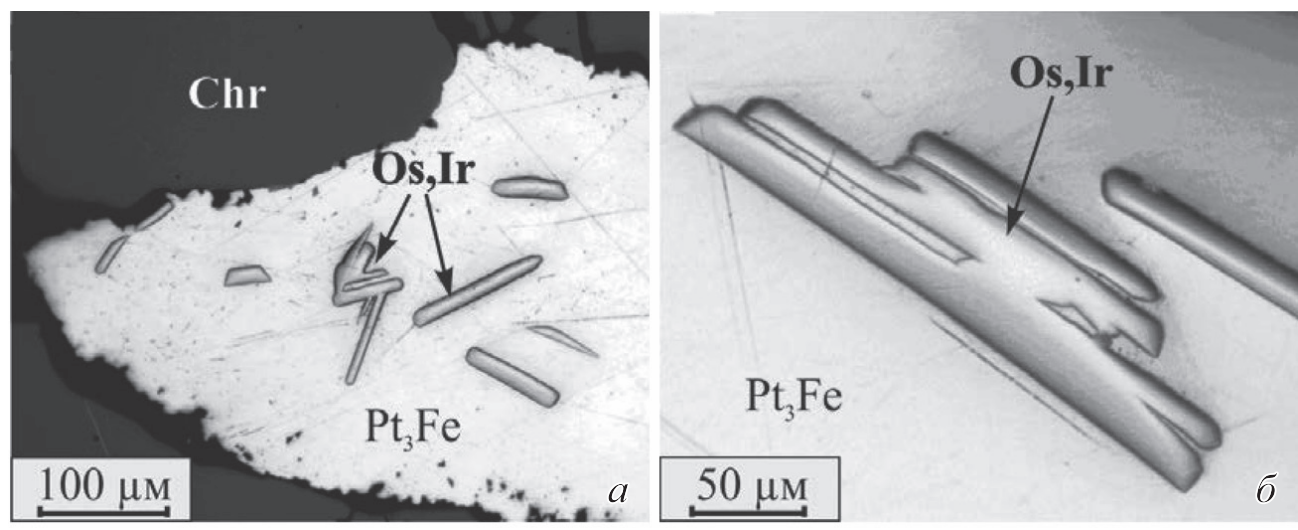

Рис. 9. Скелетные кристаллы самородного осмия в изоферроплатине. Вересовоборский массив (a), Каменушинский массив (б).

Fig. 9. Skeleton osmium crystals inside isoferroplatinum. Veresovoborsky massif (a), Kamenushensky massif (б). 


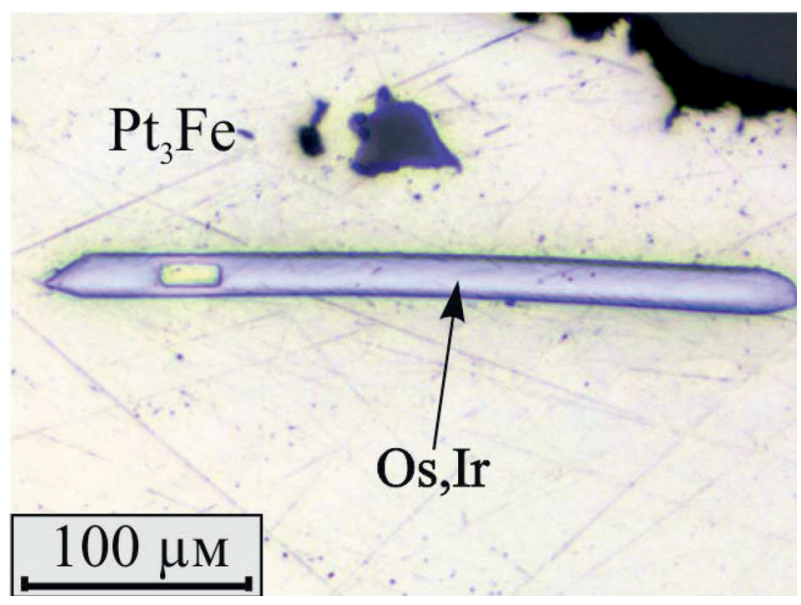

Рис. 10. Фрагмент изоферроплатины в форме отрицательного кристалла в скелетном кристалле самородного осмия.

Fig. 10. Isoferroplatinum fragment shaped as negative crystal into skeleton native osmium crystal.

зультате метасоматического замещения изоферроплатины самородным осмием. Последний вариант предположить весьма трудно, исходя из многочисленных свидетельств более раннего образования самородного осмия не только по отношению к изоферроплатине, но и по отношению к хромшпинели.

В изоферроплатине наблюдаются также выделения осмистого иридия, которые содержат захваченные фрагменты платины (рис. 11, $a$ ) или находятся в срастании с кристаллами иридистого осмия (рис. 11, б). В последнем случае осмистый иридий нарастает на пластинчатые скелетные кристаллы иридистого осмия, заполняя пространство между ветвями скелета.

К раннему рудному парагенезису относятся и сульфиды высокотемпературных платиноидов ряда лаурит-эрликманит, которые образуют идиоморф-

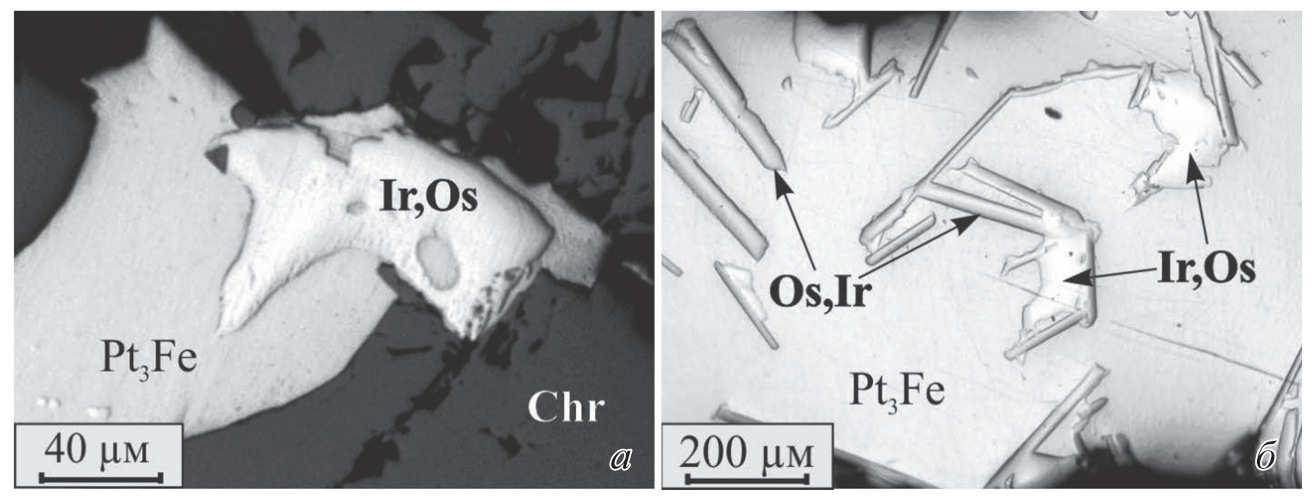

Рис. 11. Выделения самородного иридия (Ir,Os) в изоферроплатине.

$a$ - фрагменты изоферроплатины в самородном иридии, $\sigma$ - выделения иридия, нарастающие на скелетные кристаллы осмия. Каменушенский массив.

Fig. 11. Segregations of native iridium (Ir,Os) into isoferroplatinum.

$a$ - isoferroplatinum fragments into native iridium, $\sigma$ - iridium segregations overgrowing on skeleton osmium crystals. Kamenushensky massif. 


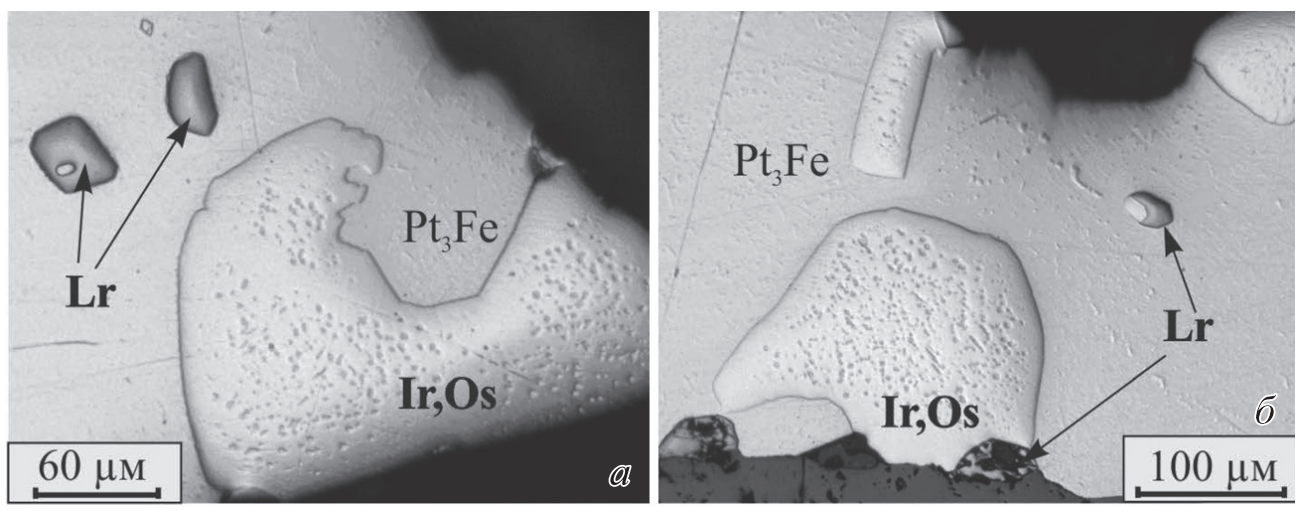

Рис. 12. Кристалл лаурита (Lr) в изоферроплатине с захваченным фрагментом изоферроплатины $(a)$, ксеноморфизм кристаллов лаурита по отношению к хромшпинели и их идиоморфизм по отношению к самородному иридию (б). Каменушенский массив.

Fig. 12. Crystal of laurite (Lr) into isoferroplatinum with its captured fragment $(a)$, xenomorphism of laurite crystals regarding to chrome-spinel and idiomorphism of them relatively to native iridium (б). Kamenushensky massif.

ные кристаллы в изоферроплатине (рис. 12). Отмечается их ксеноморфизм по отношению к хромшпинели и идиоморфизм по отношению к самородному иридию и изоферроплатине (рис. 12, б). Часто они также содержат включения изоферроплатины в виде отрицательных кристаллов (рис. 12, a).

Анализ рассмотренных взаимоотношений минералов раннего рудного парагенезиса позволяет предполагать возможность их последовательной кристаллизации из расплава. Менее вероятно образование минералов платиновой группы в результате наложенных на хромититы метасоматических процессов. Если допустить такую возможность, надо объяснить, куда выносится и в какой форме концентрируется хром при замещении хромшпинели изоферроплатиной. Еще сложнее объяснить замещение хромшпинели и изоферроплатины иридистым осмием и осмистым иридием.

В рамках магматической модели можно предположить следующую последовательность минералообразования. В обособленном от силикатной части хромитовом расплаве сначала происходила кристаллизация иридистого осмия, пластинчатые кристаллы которого впоследствии захватывались индивидами хромшпинели (рис. 6). Иридистый осмий кристаллизовался из железо-платинового расплава, сосуществовавшего с хромитовым расплавом. Часто кристаллы иридистого осмия зарождались и росли на границе между двумя жидкостями (рис. 8), что отчетливо видно на самородках изоферроплатины, отпрепарированных в процессе формирования россыпи, поверхность которых покрыта пластинчатыми кристаллами иридистого осмия (рис. 8, б). В ряде случаев отмечается преимущественный рост кристаллов иридистого осмия в сторону железо-платинового расплава (рис. 7, б). Последующая кристаллизация хромшпинели сопровождалась оттеснением железо-платинового расплава в межзерновое пространство и захватом его фрагментов, с формированием включений в виде отрицательных кристаллов (рис. 1, 3). Из железо-платинового расплава происходила кристаллизация лаурита, кристаллы которого иногда зарождались на индивидах хромшпинели (рис. 12, б), и осмистого иридия, кристаллы которого также использовали поверхности ранее образованных индивидов хромшпинели (рис. 12) и иридистого осмия (рис. $11, \sigma)$ для своего 
зарождения. Характерно, что включения иридистого осмия в хромшпинели не содержат наростов осмистого иридия, тогда как на его кристаллах, заключенных в изоферроплатине, они часто отмечаются (рис. 11). В кристаллах всех этих минералов встречены включения изоферроплатины, повторяющие по форме огранение вмещающих их минералов, что можно интерпретировать как захват ими фрагментов железоплатинового расплава в виде отрицательных кристаллов. Образование рассмотренных минералов укладывается в следующую последовательность: иридистый осмий $\rightarrow$ хромшпинель $\rightarrow$ лаурит-эрликманит $\rightarrow$ осмистый иридий $\rightarrow$ изоферроплатина.

Рассмотренная последовательность хорошо согласуется с магматической моделью образования платиноидной минерализации в клинопироксенит-дунитовых массивах (Толстых, 2004; Округин, 2004, 2011). В соответствии с предлагаемой А. В. Округиным моделью, на магматическом этапе происходит фазовое обособление хромититового расплава, который в процессе перемещения в силикатном расплаве обогащается платиноидами с образованием железо-платинового расплава — концентратора остальных металлов платиновой группы. Завершение кристаллизации хромит-платинового расплава происходит в эвтектической области, что хорошо согласуется с наблюдаемыми пространственно-временными взаимоотношениями между хромшпинелью и изоферроплатиной, которые выражаются в более ранней кристаллизации хромшпинели по отношению к изоферроплатине или в их совместном образовании.

\section{ПОСТРУДНАЯ ДЕФОРМАЦИЯ МИНЕРАЛОВ РАННЕГО РУДНОГО ПАРАГЕНЕЗИСА}

В исследованных образцах выявлены отчетливые признаки пострудной пластической и хрупкой деформаций минералов рудного парагенезиса. Она затрагивает индивиды хромшпинели, выделения изоферроплатины и находящиеся в ней кристаллы осмия, которые ведут себя по-разному в деформационном поле.

В хромшпинели отмечаются преимущественно хрупкие деформации в виде трещин, которые выполнены хроммагнетитом, серпентином или являются зияющими. Возможно, имели место и пластические деформации, но изотропность хромшпинели и сложность ее травления не позволили их выявить.

В выделениях изоферроплатины проявлена как пластическая, так и хрупкая деформации. Чуткими индикаторами пластической деформации изоферроплатины являются заключенные в ней пластинчатые кристаллы иридистого осмия. При ее деформации те из них, которые располагаются одним концом в платине, а другим в хромшпинели, частично извлекаются из хромшпинели на расстояние, соответствующее величине приоткрытия зияющих трещин в хромшпинели (рис. 13). В случае пластинчатых включений иридистого осмия, пластическая деформация проявляется как в изгибе его пластинчатых индивидов (рис. $14, a)$, так и в плавной смене цветов анизотропии, наблюдаемой при введенном анализаторе (рис. 14, б). Поскольку включения иридистого осмия находятся в псевдоморфозах тетраферроплатины по изоферроплатине, можно заключить, что пластически деформированные индивиды изоферроплатины легче подвергаются вторичным преобразованиям. Заключенные в изоферроплатине твердые, но достаточно хрупкие кристаллы иридистого осмия подвергаются и хрупкой деформации (рис. 15). 


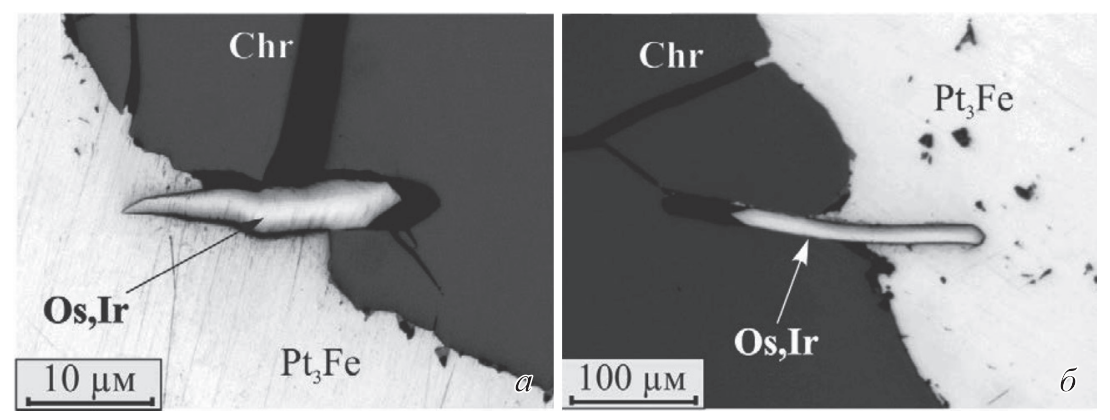

Рис. 13. Смещение кристаллов самородного осмия в процессе пластической деформации изоферроплатины. Вересовоборский массив.

Fig. 13. Displacement of osmium crystals in the process of the plastic deformation of isoferroplatinum. Veresovoborsky massif.
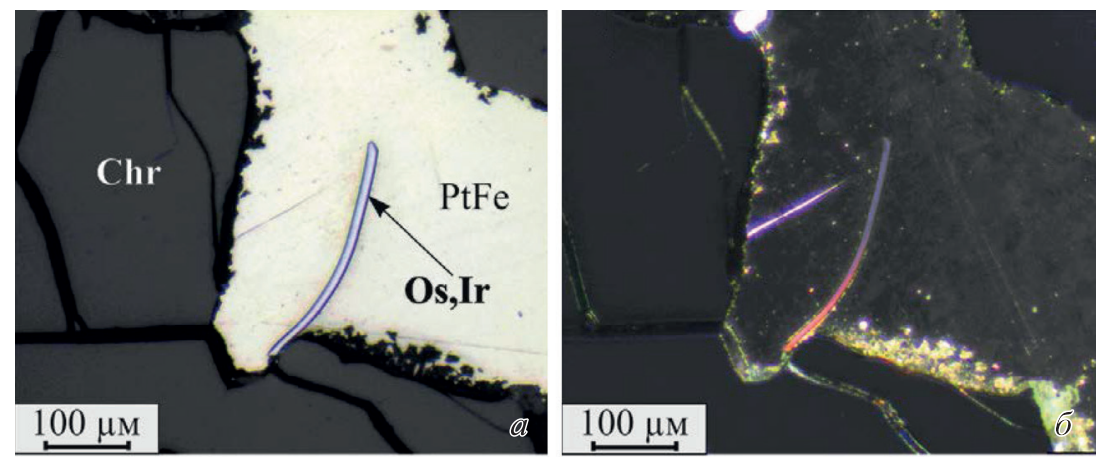

Рис. 14. Изогнутый пластинчатый кристалл самородного осмия в тетраферроплатине ( $\mathrm{PtFe})$, псевдоморфно заместившей изоферроплатину ( $a-$ без анализатора, $\sigma-$ с введенным анализатором). Вересовоборский массив.

Fig. 14. Curved lamellar osmium crystal into tetraferroplatinum (PtFe) pseudomorphically replacing isoferroplatinum $(a-$ without analyzer, $\sigma-$ with analyzer). Veresovoborsky massif.

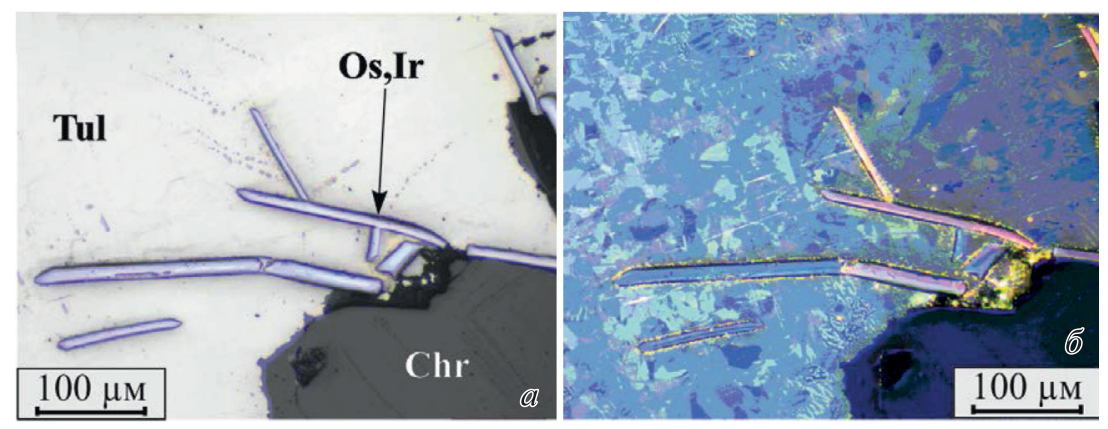

Рис. 15. Пластинчатый кристалл самородного осмия, претерпевший хрупкую деформацию в туламините (Tul), псевдоморфно заместившем изоферроплатину ( $a-$ без анализатора, $\sigma-\mathrm{c}$ введенным анализатором).

Fig. 15. Lamellar osmium crystal which has suffered fragile deformation in tulameenite (Tul) pseudomorphically replacing isoferroplatinum ( $a$ - without analyzer, $\sigma-$ with analyzer). 


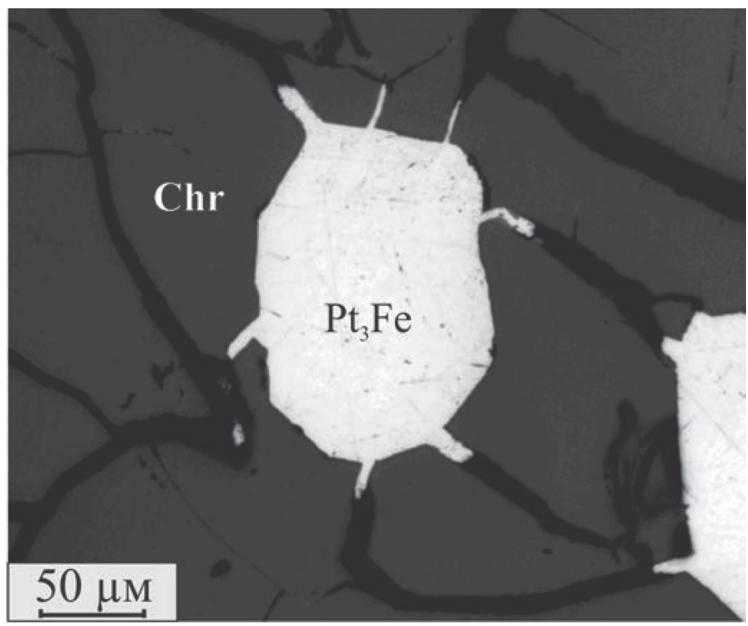

Рис. 16. Следы выдавливания изоферроплатины в трещины кристаллов хромшпинели.

Fig. 16. Traces of isoferroplatinum squeezing into fractures of chrome-spinel crystals.

Пластические деформации выделений изоферроплатины выражаются также в выдавливании ее фрагментов в трещины хромшпинели, которая в существующем поле напряжений испытывает хрупкую деформацию (рис. 16).

\section{ЗАКЛЮЧЕНИЕ}

Исследование минералов рудного парагенезиса клинопироксенит-дунитовых массивов выявило ряд онтогенических особенностей, позволяющих подойти к выбору генетической модели месторождений платиноидов в зональных клинопироксенит-дунитовых массивах.

1. Анализ взаимоотношений двух ведущих минералов рудного парагенезиса хромшпинели и изоферроплатины свидетельствует о возможности их образования во всех вариантах временно́й последовательности: более раннее образование хромшпинели, совместный рост двух фаз и более позднее образование хромшпинели, причем первый вариант наиболее вероятен.

2. Взаимоотношения индивидов иридистого осмия, осмистого иридия и лаурита с хромшпинелью и изоферроплатиной указывают на следующую последовательность их образования: иридистый осмий - хромшпинель - лаурит — осмистый иридий — изоферроплатина, что близко к ранее полученным результатам (Толстых, 2004).

3. Выявленная совокупность пространственно-временны́х взаимоотношений минералов раннего рудного парагенезиса хорошо согласуется с представлениями об их образовании и концентрировании на магматическом этапе становления зональных клинопироксенит-дунитовых массивов (Округин, 2004, 2011).

4. Процессы замещения изоферроплатины туламинитом и тетраферроплатиной, а хромшпинели магнетитом, связанные с поздней серпентинизацией дунитов, не приводят к существенному перераспределению металлов платиновой группы. 
5. Признаки пострудной деформации хромшпинели и минералов платиновой группы позволяют рассматривать рудную минерализацию как более раннюю по отношению к деформационным процессам, проявленным в дунитах.

Выявленные закономерности должны определяться особенностями строения и эволюции клинопироксенит-дунитовых массивов, что может быть положено в основу поисков коренной платиновой минерализации.

\section{Работа выполнена при поддержке гранта РФФИ № 18-35-00151\18.}

\section{Список литературы}

Бетехтин А. Г. Платина и другие минералы платиновой группы. М.; Л.: Изд. АН СССР, 1935. $148 \mathrm{c}$.

Борисов А. А. Кристаллизация и стабильность сплавов благородных металлов в магматическом процессе. Геология рудных месторожд. 2005. № 6. С. 516-524.

Волченко Ю. А. Парагенезисы платиноидов в хромитовых рудах Урала / Петрология и рудообразование. Свердловск: УНЦ АН СССР, 1986. С. 56-63.

Высоикий Н. К. Месторождения платины Исовского и Нижнетагильского районов на Урале. Выпуск 1. Текст. // Труды геологического комитета. Новая серия. 1913. Вып. 62. 696 с.

Генкин А. Д. Последовательность и условия образования минералов платиновой группы в Нижнетагильском дунитовом массиве // Геол. рудн. месторожд. 1997. Т. 39. № 1. С. 41-48.

Григорьев Д. П. Онтогения минералов. Львов: Изд-во Львовского ун-та, 1961. 283 с.

Завариикий А. Н. Коренные месторождения платины на Урале. Геологический комитет. Материалы по общей и прикладной геологии. Выпуск 108. Л., 1928. 61 с.

Иванов О. К. Концентрически-зональные пироксенит-дунитовые массивы Урала. Екатеринбург: Изд-во Уральского ун-та, 1997. 488 с.

Иванов К. С. Генезис хром-платинового оруденения Уральского (Нижнетагильского) типа // Доклады РАН. 2011. Т. 441. № 2. С. 224-226.

Карпинский А. П. О коренном месторождении платины на Урале // Записки АН, 1893. Т. 71. C. $222-229$.

Карпинский А. П. О вероятном происхождении коренных месторождений платины уральского типа. I // Известия АН СCCP. VI серия. 1926. Т. 20. Вып. 1-2. С. 133-170.

Малич К. Н., Лопатин Г. Г. Новые данные о металлогении уникального Гулинского клинопироксенит-дунитового массива (Северная Сибирь, Россия) // Геол. рудн. месторожд. 1997. T. 39. № 3. C. $247-257$.

Малич К. Н., Степанов С. Ю., Баданина И. Ю., Хиллер В. В. Минеральные ассоциации платиноидов Светлоборского, Вересовоборского и Нижнетагильского клинопироксенит-дунитовых массивов Среднего Урала // Вестник Уральского отделения Российского минералогического общества. 2015. № 12. С. $65-83$.

Мосин К. И. История добычи платины на Урале. Нижняя Тура: Нижнетуринская типография, 2002. 246 с.

Округин $A$. B. Кристализационно-ликвационная модель формирования платиноидно-хромитовых руд в мафит-ультрамафитовых комплексах // Тихоокеанская геология. 2004. Т. 23. № 2. C. $63-75$.

Округин A. B. Образование крупных самородков платины в хромититовых рудах мафит-ультрамафитовых пород // Наука и образование. 2011. № 3. С. 16-20.

Пушкарев Е. В., Каменеикий В. С., Морозова А. В., Хиллер В. В., Главатских С. П., Родеманн $T$. Онтогения рудных хромшпинелидов и состав включений как индикаторов пневматолито-гидротермального образования платиноносных хромититов массива Кондер (Алданский щит) // Геол. рудн. месторожд. 2015. Т. 57. № 5. С. $394-423$.

Пушкарев Е. В., Аникина Е. В., Гарути Дж., Заккарини Ф. Хром-платиновое оруденение нижнетагильского типа на Урале: Структурно-вещественная характеристика и проблема генезиса // Литосфера. 2007. № 3. С. 28-65.

Степанов С. Ю. Онтогения минералов платиновой группы зональных ультрамафических массивов (Средний Урал) / Мат. конф. «Онтогения, филогения и система минералогии». Миасс: Институт минералогии УрО РАН, 2015. С. 182-186. 
Степанов С. Ю., Малич К. Н., Козлов А. В., Баданина И. Ю., Антонов А. В. Платиноидная минерализация Светлоборского и Вересовоборского клинопироксенит-дунитовых массивов Среднего Урала (Россия) // Геол. рудн. месторожд. 2017. Т 59. № 3. С. 238-250.

Tолстых H. Д. Минеральные ассоциации платиноносных россыпей и генетические корреляции с их коренными источниками. Автореф. дис. ... докт. г-м. наук. Новосибирск, 2004. 33 с.

Толстых Н. Д., Телегин Ю. М., Козлов А. П. Коренная платина Светлоборского и Каменушенского массивов платиноносного пояса Урала // Геология и геофизика. 2011. Т. 52. № 6. C. $775-793$.

\section{References}

Auge T., Genna A., Legendre O., Ivanov K. S., Volchenko Yu. A. Primary platinum mineralization in the Nizhny Tagil and Kachkanar ultramafic complexes, Urals, Russia: A genetic model for PGE concentration in chromite-rich zones. Econ. Geol. 2005. Vol. 100. P. 707-732.

Betekhtin A. G. Platinum and other platinum group minerals. Moscow; Leningrad: USSR Academy of Science, 1935. 148 p. (in Russian).

Genkin A. D. Consequence and conditions of the platinum group minerals in the Nizhnetagilsky dunite massif. Geol. Ore Deposits. 1997. Vol. 39. N 1. P. $41-48$ (in Russian).

Grigoryev D. P. Ontogeny of minerals. Lvov: Lvov University, 1961. 283 p.

Ivanov $O$. K. Concentric-zonal pyroxenite-dunite massifs of the Urals. Ekaterinburg: Ural. University, 1997. 488 p. (in Russian).

Ivanov K. S. Genesis of chromium-platinum ore mineralization of the Uralian (Nizhnii Tagil) type. Doklady Earth Sci. 2011. Vol. 441. N 1. P. 1489-1491.

Johan Z. Alaskan-type complexes and their platinum-group element mineralization. In: The Geology, Geochemistry, Mineralogy and Mineral Beneficiation of Platinum-Group Elements. Canad. Inst. Mining, Metall. Petrol. 2002. Special Vol. 54. P. 669-719.

Karpinsky A. P. About the bedrock platinum deposit in the Urals. Notes Academ. Sci. 1893. Vol. 71. P. 222-229 (in Russian).

Karpinsky A. P. About probable origin of platinum deposits of the Urals type. Trans. USSR Acad. Sci. 1926. VI ser. Vol. 20. Iss. 1-2. P. 133-170 (in Russian).

Malich K. N., Lopatin G. G. New data on the metallogeny of the unique Guli clinopyroxenite-dunite massif (Northern Siberia, Russia). Geol. Ore Deposits. 1997. Vol. 39. N 3. P. 247-257 (in Russian).

Malich K. N., Stepanov S. Yu., Badanina I. Yu., Hiller V. V. Mineral associations of platinoids in Svetloborsky, Veresovoborsky and Nizhnetagil'sky clinipyroxenite-dunite massifs of the Middle Urals. Report. Urals Division Russian. Miner. Soc. Yekaterinburg, 2015. N 12. P. 65-83 (in Russian).

Malitch K. N., Thalhammer O. A. R. Pt-Fe nuggets derived from clinopyroxenite-dunite massifs, Russia: a structural, compositional and osmium-isotope study. Canad. Miner. 2002. Vol. 40. P. 395418.

Mosin K. I. The history of platinum mining in the Urals. Nizhnyaya Tura, 2002. 246 p. (in Russian).

Okrugin A. V. Crystallization-liquation model of the formation of PGE-chromitites ores in mafic-ultramafic complexes. Russian J. Pacific Geol. 2004. Vol. 23 N 2. P. 63 -75 (in Russia).

Okrugin $A$. $V$. The formation of large nuggets of platinum in the chromite ores of mafic-ultramafic rocks. Sci. Education. 2011. N 3. P. 16-20 (in Russia).

Pushkarev E. V., Kamenetsky V. S., Morozova A. V., Hiller V. V., Glavatskikh S. P., Rodemann T. Ontogeny of ore Cr-spinel and composition of inclusions as indicators of the pneumatolytic-hydrothermal origin of PGM-bearing chromitites from Kondyor massif, the Aldan Shield. Geol. Ore Deposits. 2015. Vol. 57. N 5. P. $352-380$.

Pushkarev E. V., Anikina E. V., Garuti J., Zakkarini F. Chromium-platinum deposits of Nizhny-Tagil type in the Urals: structural-substantial characteristic and a problem of genesis. Lithosfera. 2007. N 3. P. $28-65$ (in Russian).

Stepanov $S$. Yu. Ontogeny of platinum group minerals in zonal ultramafite massifs (the Middle Urals). In: Proc. Conf. «Ontogeny, Phylogeny and the System of Mineralogy». Miass, 2015. P. 182186 (in Russian).

Stepanov S. Yu., Malich K. N., Kozlov A. V., Badanina I. Yu., Antonov A. V. Platinum group element mineralization of the Svetly Bor and Veresovy Bor clinopyroxenite-dunite massifs, Middle Urals, Russia. Geol. Ore Deposits, 2017. Vol. 59. № 3. P. 244-255. 
Tolstykh N. D. Mineral associations of platinum-bearing placers and their genetic correlations with primary sources. D. Sc. thesis syn. Novosibirsk, 2004. 33 p. (in Russian).

Tolstykh N. D., Telegin Yu. M., Kozlov A. P. Platinum mineralization of the Svetloborsky and Kamenushinsky massifs (Urals Platinum Belt). Russian Geol. Geophys. 2011. Vol. 52. N 6. P. $603-$ 619.

Volchenko Yu. A. Parageneses of platinoids in the Urals chromite ores. In: Petrology and ore-forming. Sverdlovsk, 1986. P. 56-63 (in Russian).

Vysotsky N. K. Platinum deposits of the Isovsky and Nizhne-Tagilsky regions in the Urals. Works of the Geological Committee. New series. 1913. N 62. 692 p. (in Russian).

Zavaritskiy A. N. Bedrock platinum deposits in Ural. Leningrad: Geological Committee, 1928. 56 p. (in Russian).

Поступила в редакцию 14 декабря 2017 г. 